procurement-mercks-investigational-antiviral-medicine-covid-19-treatment. html. Published 2021. Accessed January 18, 2022

8. Biden administration secures 10 million courses of Pfizer's COVID-19 oral antiviral medicine as additional tool to reduce hospitalizations and save lives. US Department of Health and Human Services website. https:// www.hhs.gov/about/news/2021/11/18/biden-administration-secures10-million-courses-pfizers-covid-19-oral-antiviral-medicine-as-additional-toolreduce-hospitalizations-save-lives.html. Published 2021. Accessed January 18, 2022 .
9. Doernberg SB, Abbo LM, Burdette SD, et al. Essential resources and strategies for antibiotic stewardship programs in the acute-care setting. Clin Infect Dis 2018;67:1168-1174.

10. Dyar OJ, Beović B, Pulcini C, Tacconelli E, Hulscher M, Cookson B. ESCMID generic competencies in antimicrobial prescribing and stewardship: towards a European consensus. Clin Microbiol Infect 2019;25:13-19.

11. Dik JW, Poelman R, Friedrich AW, et al. An integrated stewardship model: antimicrobial, infection prevention and diagnostic (AID). Future Microbiol 2016;11:93-102.

\title{
Antibiotics against viruses: Brazilian doctors adrift
}

\section{Heslley Machado Silva* (1)}

Education, Health and Science Department, University Center of Formiga (UNIFOR/MG), Formiga City, Brazil and State University of Minas Gerais (UEMG), Ibirité City, Brazil

To the Editor-As of the beginning of April 2021, Brazil is experiencing a unique moment in the coronavirus disease 2019 (COVID-19) pandemic. The number of cases of and deaths from the disease has never been so high. At the same time, drugs that have not been scientifically demonstrated to be effective against COVID-19 are increasingly being prescribed, both for early treatment and even for prevention.

This growing phenomenon is dangerous. An increasing number of doctors, and even doctors' associations, support the socalled COVID kit, a set of innocuous drugs, which supposedly would stop the progress of the disease. These doctors implicitly endorse a health policy ${ }^{1}$ that wastes resources and efforts that could otherwise be directed to purchase of material to combat the disease, planning of pandemic control actions, and support of vaccination efforts.

Misinformation (ie, "fake news") and conspiracy theories about the disease and supposedly effective treatments against the severe acute respiratory coronavirus virus 2 (SARS-CoV-2) virus abound. ${ }^{2}$ In the academic world, there is no doubt that the improper and indiscriminate use of any medication can adversely affect the health of the population, and it is no different with COVID-19, even though many Brazilian doctors claim exactly the opposite on social networks. A responsible doctor would refrain from recommending (or prescribing) a medication without any discussion of its risks and possible side effects. ${ }^{3}$

One of the great achievements in the history of medicine, revolutionizing the treatment of bacterial infections, was the systematic discovery and use of antibiotics, starting with the work of Alexander Fleming ${ }^{4}$ in the first half of the last century and continuing to the present day. Antibiotics should be used to prevent and treat infections caused by bacteria, not those caused by viruses, since they are not effective against viruses.

Nevertheless, in the fight against COVID-19 in Brazil, azithromycin is prescribed on a large scale. In 2020, sales of the antibiotic increased $43.6 \%$. This use of the drug is based on in vitro studies ${ }^{5}$ that demonstrated some antiviral effect. But it would be necessary to test it on patients to prove any practical results, which unfortunately did not occur before it started to be prescribed. Since the

*Author for Correspondence: Heslley Machado Silva, Email: heslley@uniformg.edu.br Cite this article: Silva HM. (2022). Antibiotics against viruses: Brazilian doctors adrift. Infection Control \& Hospital Epidemiology, 43: 1992-1993, https://doi.org/10.1017/ ice.2021.434 first months of the pandemic, azithromycin has been prescribed either preventively or in early treatment. When compared to the standard treatment, there were no significantly better results for azithromycin. $^{6}$

Exacerbating the problem is that azithromycin is being widely prescribed in conjunction with other medications, such as the anthelmintic ivermectin, which had a large increase in sales in Brazil in 2020, and the antimalarial hydroxychloroquine, which is widely touted for use against COVID-19, although clinical trials have found it ineffective and dangerous. Useless against COVID-19 and potentially dangerous separately, these drugs pose even more of a potential danger in combination. ${ }^{7}$

Azithromycin is a formidable drug, capable of fighting a broad spectrum of bacterial infections by inhibiting protein synthesis, very safe with relatively mild side effects at the doses indicated for its intended use and has proven to be very effective against infections of the respiratory tract, skin, and genital tract in particular. Azithromycin is an important tool for the control of diseases worldwide. $^{8}$ It may play a limited role even in the treatment of COVID-19, if there is a bacterial coinfection of the lungs. ${ }^{9}$

But when used in a way inconsistent with its established protocol, dosage, and usage, it is unclear what its effect on patients who are ill with COVID-19 would be. Therefore, the first recommendation should be caution, abundant caution, until welldesigned clinical trials can be developed and completed. ${ }^{10}$ But the Brazilian logic, even among many physicians, is that since we do not have any drug effective against SARS-CoV-2, we should try anything, at any dose, without considering the risks.

If the effect of the misuse of azithromycin on COVID-19 patients is unclear, the effect of its misuse on the general population is not. Intense use of azithromycin selects for bacterial resistance. A populous and diverse country suffering from social inequalities and chronic deficiencies in basic sanitation and prevention of sexual diseases, Brazil may serve as a perfect evolutionary laboratory for azithromycin-resistant strains of bacteria. Consequently, there is a very real risk that Brazil will have difficulties treating severe cases of many infectious diseases, such as childhood diarrhea, typhoid fever, syphilis, and gonorrhea, in the coming years. Thanks to the wide misuse of azithromycin to treat COVID-19 patients in Brazil, a well-tested and relatively 
inexpensive tool to combat diseases that disproportionately affect underserved populations in the country may be irretrievably lost.

Acknowledgments. I thank Dr Glenn Branch, Deputy Director National Center for Science Education (NCSE), Oakland, California, who kindly assisted me in producing this text with a review of the English.

Financial support. No financial support was provided relevant to this article.

Conflicts of interest. The author reports no conflicts of interest relevant to this article.

\section{References}

1. Silva HM. Medicines and illusions in the fight against COVID-19 in Brazil. Ethics Med Public Health 2021;16:100622.

2. Orso D, Federici N, Copetti R, Vetrugno L, Bove T. Infodemic and the spread of fake news in the COVID-19-era. Eur J Emerg Med 2020;27:327-328.

3. Islam MS, Sarkar T, Khan SH, et al. COVID-19-related infodemic and its impact on public health: a global social media analysis. Am J Trop Med Hyg 2020;10:1621-1629.
4. Fleming A. Penicillin. Br Med J 1941;2:386.

5. Echeverría-Esnal D, Martin-Ontiyuelo C, Navarrete-Rouco ME, et al. Azithromycin in the treatment of COVID-19: a review. Expert Rev Anti Infect Ther 2021;19:147-163.

6. Furtado RHM, Berwanger O, Fonseca HA, et al. Azithromycin in addition to standard of care versus standard of care alone in the treatment of patients admitted to the hospital with severe COVID-19 in Brazil (COALITION II): a randomised clinical trial. Lancet 2020;396:959-967.

7. Alizargar J. Dangers of the use of hydroxychloroquine and azithromycin combination in COVID-19 patients. Travel Med Infect Dis 2020;38:101881.

8. Peters DH, Friedel HA, McTavish D. Azithromycin. Drugs 1992;44: 750-799.

9. Oldenburg CE, Doan T. Azithromycin for severe COVID-19. Lancet 2020;396:936-937.

10. Venditto VJ, Haydar D, Abdel-Latif A, et al. Immunomodulatory effects of azithromycin revisited: potential applications to COVID-19. Front Immunol 2021;12:285.

\title{
The quiet before the storm: Negligence and inappropriateness in face mask use in the community preceded devastating second wave of coronavirus disease 2019 (COVID-19) in Brazil
}

\author{
Nicole de Micy Ferreira Cintra MS, Thales Cabral Benini Felisberto MS, Ingrid Costa Limeira MS, \\ Moriê Letícia Dalera de Carli MS, Thamyres Siqueira Cruz MS, Gabriel Manha dos Santos MS, \\ Laura de Camargo Vaz MS, Lucas Andrade Toledo MS, Cristiane Ravagnani Fortaleza RN, \\ Lenice do Rosário de Souza MD, PhD and Carlos Magno Castelo Branco Fortaleza MD, PhD (1) \\ Department of Infectious Diseases, Botucatu Medical School, Universidade Estadual Paulista (UNESP), City of Botucatu, State, Brazil
}

To the Editor-As of June 2021, Brazil has approached 500,000 deaths from coronavirus disease 2019 (COVID-19, https://covid. saude.gov.br/). Hundreds of patients die every day while awaiting intensive care unit beds. Hospitals face shortages of hypnotic drugs and muscle relaxants for patients requiring mechanical ventilation. ${ }^{1}$ The Brazilian president's denialism, ${ }^{2}$ lack of vaccines, ${ }^{3}$ and lack of coherent social distancing policies ${ }^{3}$ have undermined COVID-19 control. We hypothesize that, both as an additional factor and as consequence of the previously cited failures, population negligence in using face masks was one of the triggers of the devastating second wave that threatens Brazil since January 2021.

We conducted a cross-sectional study to analyze predictors of no use of masks or incorrect mask use (masks not covering nose or mouth) in the commercial center of Botucatu, a city with 150,000 inhabitants located in inner São Paulo State, Brazil. This city is the central hub of a regional health division and is home to a Public Medical School and a teaching hospital. It has been severely threatened by COVID-19 since April 2020. After a peak

Author for correspondence: Carlos Magno Castelo Branco Fortaleza, E-mail: carlos. fortaleza@unesp.br

Cite this article: Cintra N, et al. (2022). The quiet before the storm: Negligence and inappropriateness in face mask use in the community preceded devastating second wave of coronavirus disease 2019 (COVID-19) in Brazil. Infection Control \& Hospital Epidemiology, 43: 1993-1995, https://doi.org/10.1017/ice.2021.395 of cases in July 2020, a gradual decrease in that number occurred until November, when case numbers started to increase again. ${ }^{5}$

Our study was conducted from September 21 through 27. During that period, the so-called "São Paulo Plan" (https://www. saopaulo.sp.gov.br/planosp/), which provided for the calibration of mobility restrictions according to COVID-19 epidemiological indicators, was in a phase of partial relaxation. However, a governmental decree mandated the use of face masks in public places and required retail stores to restrict entry to $25 \%$ of their usual costumers. Therefore, crowding on the sidewalks was common.

We estimated sample size of 767 in OpenEpi software (Emory University, Atlanta, GA), for a total population of 150,000 , unknown prevalence of not using masks, 5\% precision in results, and effect design of 2 . That sample was expanded to achieve balanced distribution of observations per weekday and period.

The research team circulated through retail streets in cars with closed windows, following a constant and predetermined route, in the morning, afternoon and evening of each day of the week. These observations were conducted for the first 50 people seen in each repetition of the route. In total, 150 daily nonduplicate observations were recorded $(\mathrm{N}=1,050)$. Study participants were characterized by sex, apparent age (through concordance of 2 investigators), period, and weekday. Multivariable logistic 